\title{
How does justice smell? Reflections on space and place, justice and the body
}

\begin{tabular}{|c|c|}
\hline \multicolumn{2}{|c|}{$\begin{array}{l}\text { Author: } \\
\text { Jacob Meiring }\end{array}$} \\
\hline \multicolumn{2}{|c|}{$\begin{array}{l}\text { Affiliation: } \\
{ }^{1} \text { Centre for the Advancement } \\
\text { of Scholarship, University of } \\
\text { Pretoria, South Africa }\end{array}$} \\
\hline \multicolumn{2}{|c|}{$\begin{array}{l}\text { Project leader: J.C. Müller } \\
\text { Project number: } 02380595\end{array}$} \\
\hline \multicolumn{2}{|c|}{$\begin{array}{l}\text { Description: } \\
\text { This research of Dr Jacob } \\
\text { Mering is based on his } \\
\text { participation in the } \\
\text { Theological cluster of the } \\
\text { Ubuntu Research Project, } \\
\text { directed by Prof. Dr Julian } \\
\text { Müller, Centre for the } \\
\text { Advancement of Scholarship, } \\
\text { University of Pretoria, } \\
\text { South Africa. }\end{array}$} \\
\hline \multicolumn{2}{|c|}{$\begin{array}{l}\text { Corresponding author: } \\
\text { Jacob Meiring, } \\
\text { jacob@bodytheology.co.za }\end{array}$} \\
\hline $\begin{array}{l}\text { Dates: } \\
\text { Received: } 17 \text { I } \\
\text { Accepted: } 19 \\
\text { Published: } 14\end{array}$ & $\begin{array}{l}\text { May } 2016 \\
\text { Aug. } 2016 \\
\text { Nov. } 2016\end{array}$ \\
\hline \multicolumn{2}{|c|}{$\begin{array}{l}\text { How to cite this article: } \\
\text { Meiring, J., 2016, 'How does } \\
\text { justice smell? Reflections on } \\
\text { space and place, justice and } \\
\text { the body', HTS Teologiese } \\
\text { Studies/Theological Studies } \\
\text { 72(1), a3492. http://dx.doi. } \\
\text { org/10.4102/hts.v72i1.3492 }\end{array}$} \\
\hline \multicolumn{2}{|c|}{$\begin{array}{l}\text { Copyright: } \\
\text { @ 2016. The Authors. } \\
\text { Licensee: AOSIS. This wo } \\
\text { is licensed under the } \\
\text { Creative Commons } \\
\text { Attribution License. }\end{array}$} \\
\hline \multicolumn{2}{|l|}{ Read online: } \\
\hline 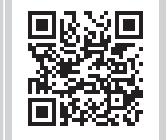 & $\begin{array}{l}\text { Scan this QR } \\
\text { code with your } \\
\text { smart phone or } \\
\text { mobile device } \\
\text { to read online. }\end{array}$ \\
\hline
\end{tabular}

Flowing from a joint consultation on Spatial Justice and Reconciliation on 21-22 September 2015, hosted by the Centre for Contextual Ministry and the Ubuntu Research Project of the University of Pretoria, this article reflects on the notions of space and justice from the perspective of a contemporary theological anthropology as 'embodied sensing', where the making of meaning is sensed in the body. The argument is put forward that spatial justice is an embodied endeavour and that it cannot be achieved disconnected from the bodies of the persons in the concrete context where justice is strived for and where bodies can flourish. The relation between spatial justice, sense of place, human flourishing and the embodied sensing of meaning is explored.

\section{Introduction}

Is this how justice smells? The stench from the decaying corpses of animals in a pit nearby whiffed into the bus where we, a group of theologians, church workers and community activists from South Africa, Zimbabwe and Kenya, ${ }_{1}^{1}$ were parked on a manmade hillock overlooking the dump site on the outskirts of Mamelodi township, and still further away from the affluent east of Pretoria, South Africa. It was not safe for us to go any closer. The supervisor of the site heaved himself into the bus, recounting the layout and workings of the dump site, his words mingling with the stench outside. He told us of the different groups recycling different kinds of waste, how much they were earning per kilogram compared to what the recycling company received (and I thought the company did the recycling themselves); he told us of people giving birth on the site, of occasional police raids and the people, mostly illegal immigrants from Zimbabwe, disappearing for a day or two only to return and make their livelihood on the site; and he also told us of fights between the different groupings on the site and how dangerous it could be. There was a certain desperation in his voice, but also an empathy. A participant from Zimbabwe sitting next to me explained that these immigrants were treated as garbage in Zimbabwe, mainly coming from a group that opposed the governing party there ... and now they work with garbage in these desperate circumstances.

This scenario is not unique to the greater region of Tshwane. In a recent security assessment report to the Msunduzi municipality, recommendations were made to increase security measures at the New England Road landfill site, Pietermaritzburg, and to allow security guards to shoot waste pickers with pellet guns as a last resort (Pillay 2015). The report states that waste pickers continuously damage the fencing around the site, build illegal structures to sell goods and sleep on the site which is not permitted. It continues that the private contracted security guards are unable to control the tip pickers from ... scattering all over the site thereby intimidating customers and standing outside the main gate waiting to jump into customers' vehicles'. A decision was also made to build three high-security towers at strategic points to monitor the entire dump site. A few days after the release of this report, police used rubber bullets and stun grenades to disperse a group of more than 100 waste pickers who protested the city's decision to stop all waste picking on a site near Sobantu, Pietermaritzburg, where companies dump dangerous goods and expired food, citing safety and health concerns (Mbombvu 2015). A spokesperson for the municipality said that there were also reports of violent incidents. One of the waste pickers at the protest, the 42-year-old Nokukhanya Myeza, a single mother with four children, described her frustration:

$1.0 n 21$ and 22 September 2015, the Unit for Social Cohesion and Reconciliation in the Centre for Contextual Ministry at the University of Pretoria, in conjunction with the Religious Cluster of the Ubuntu Research Project, sponsored by the Templeton Foundation, hosted a 2-day conversation with the theme, Spatial justice and reconciliation: discerning a theological agenda. The first day comprised a spatial immersion where participants visited various locations in the east of Pretoria, starting with Hatherley landfill site on the outskirts of Mamelodi township.

Note: This article is part of the Special Collection titled 'Spatial Justice and Reconciliation', sub-edited by Stephan de Beer, of the Department of Practical Theology and the Centre for Contextual Ministry, University of Pretoria. 
I have been picking up items from the dump site for years. It came as a shock when we were told that we are now not allowed to pick up items from the site. I pick up food and that helps to feed my children ... some of the women pick up cardboard. They take it to recycling companies. We are not working and this is how we feed our families. We were told the municipality will install cameras and that they will order the security guards to shoot us. (Mbomvu 2015)

Is this how justice smells? The question implies that justice, as well as the effect of justice in a particular space, is a bodily enterprise. I want to explore this notion from the perspective of a model I have proposed for a contemporary theological anthropology as embodied sensing. In a recent paper ${ }^{2} \mathrm{I}$ have expanded the notion of embodied sensing based on the work of the Irish philosopher Richard Kearney to the embodied sensing of meaning. I argue that the embodied sensing of meaning correlates to the idea of human flourishing and I explore the link between spatial justice and the notion of 'sense of place'.

\section{The embodied sensing of meaning}

I have recently proposed a model for a contemporary theological anthropology as embodied sensing, which I argue functions within the intimate triangle of the lived body, language and experiencing within a concrete context, with an openness to the 'more than', to that which lies beyond the boundaries of the skin (Meiring 2015:3 of 8).

My own rendering of sensing as embodied sensing was inspired by the body theology of James Nelson who makes the assertion in his 1978 book that 'body theology begins with the concrete' and not with doctrines or creeds or problems in tradition. It begins with the concrete and 'the fleshly experience of life - with our hungers and our passions, our bodily aliveness and deadness' (Nelson 1992:43). He considers 'lived experience' to be the most neglected in theology. Nelson writes that for many, theology is a 'second moment' and that the first moment is 'life itself', that 'theology comes afterward, attempting to understand and serve life' (Nelson 2004:12).

It was influenced by the book Philosophy in the flesh (1999) by George Lakoff and Mark Johnson. They define 'philosophy in the flesh' as 'a way to know ourselves better, to see how our physical being - flesh, blood, and sinew, hormone, cell, and synapse - and all things we encounter daily in the world make us who we are' (Lakoff \& Johnson 1999:568). Their philosophy in the flesh also builds upon the insights of cognitive science with its research on notions of concepts, language, reason and feeling and in doing so, they promote a conversation between philosophy and cognitive science; they view the latter as one of the most significant resources for self-knowledge.

It was inspired by the work of Maxime Sheets-Johnstone whose dedicated examination of the corporeal turn requires

2.Unpublished paper, 'Theological anthropology as embodied sensing: consciousness and the mapping of the body', delivered at the annual conference, Creation, Consciousness and Christology: Evolutionary Perspectives of the South African Science and Religion Forum (SASRF) in Pretoria from 16 to 18 September 2015. an openness to interdisciplinary investigations. The disciplines she links in her research hold the body as foundation and 'testify to the rich and complex dimensions of bodily being' and that such interdisciplinary research 'attest(s) to the importance of exploring the living realities of corporeal life and of understanding in the deepest sense in each instance what it means to be the bodies we are' (Sheets-Johnstone 2009:3). She claims that to meet the challenge of languaging dynamic experience 'is to be true to the truths of the experience'. These dynamic experiences refer to the 'complex diversity of feelings and thoughts that exceed the bounds of everyday language because they are experienced dynamically'. She proposes a methodology along phenomenological lines that 'demands our drawing back from an easy, ready-made everyday language and our turning first of all to experience itself'. To be able to do this, she continues that we have to 'bracket' our natural attitude towards the world and 'thereby meet an experience as if for the first time' (Sheets-Johnstone 2009:378).

The term 'sensing' also endeavours to capture what the linguistic philosopher and psychologist Eugene Gendlin conveys with the word 'focussing' and Les Todres with the expression 'embodied understanding'. Todres defines 'embodied understanding' as 'a form of knowing that evokes the possibility of living, bodily relevant textures and meanings' (Todres 2011:2). He in turn builds upon Gendlin's notion of focussing, which is about paying attention to the words that work, responding to an experience where language captures the felt sense of a word in the body. It is a focus on texture where a phenomenon is not merely a theoretical description of an occurrence, but a live moment that was embodied by a person in a concrete situation. Embodied sensing is then a move away from a pure cognitive, objective approach and is derived from the Latin word sensus, which expresses the faculty of thought, feeling and meaning all in one.

I was pleasantly surprised when I encountered the same sentiment in the recent book, Carnal hermeneutics (2015), edited by Richard Kearney and Brian Treanor. For them, carnal hermeneutics provides a philosophical approach to 'the body as interpretation', trying to answer the questions of how we make sense 'of bodies with our bodies' and how to 'read between the lines of flesh and skin' (Kearney \& Treanor 2015:1). Their hermeneutical project endeavours to 'go all the way down' and to abandon 'residual tendencies to oppose language to sensibility, word to flesh, text to body' and to realise that 'all experience, from birth to death, is mediated by our embodiment and only makes sense of sense accordingly' (Kearney \& Treanor 2015:2). The challenges for the ongoing project of carnal hermeneutics are what they call 'a radical commitment' to interdisciplinary dialogue (with disciplines such as linguistics, theology, poetics, anthropology, politics and psychoanalysis) and to rethink the enigma of flesh'. This implies that 'flesh' cannot be reduced to a phenomenological version of the body, but should be recognised as a medium that connects humans to 'the flesh of 
the world'. Kearney states that his constant intention is to demonstrate 'how carnal phenomenology is intimately and ultimately carnal hermeneutics'. Kearney and Treanor refer to flesh as 'the edge' where a human meets 'worlds that exceed and entreat it - animal and environmental, sacred and profane' $^{\prime}$ 2015:11).

Maurice Merleau-Ponty gives an account of 'diacritical sensation' as a new mode of expressing a sensibility that lies in the crossing between sensation and language. Meaning is not construed through isolated objects or terms, but 'as parts of a mobile interaction of signs involving intervals. Absences, folds and gaps' (Kearney 2015:42). There is a gap in a level of meaning that is not related to an object. This gap relates to the structure of perception and is not merely a function of language. Kearney interprets diacritical perception through gaps as an indication of the inadequate correlation between consciousness and object. MerleauPonty insists that 'the sensing of meaning' is expressed through diacritical perception in these intervals, these gaps between our experiences and objects (Kearney 2015:43).

There is sufficient confluence between what I strive to achieve with the notion of embodied sensing and sensing in Kearney's carnal hermeneutics as diacritical hermeneutics (after Merleau-Ponty) to indicate that sensing here is an effort to find a grammar of the flesh, where flesh refers to the spacing between the intimate body and object. Kearney states that it is the task of carnal hermeneutics to find a balance between 'the movement of same towards other and other towards same': a balance between body and flesh, between language and body (Kearney 2015:55). He then enquires about the kind of language we are talking about, 'one not only of words and writing, surely, but also of sensing and touching ... not only of intellectual "understanding" but also of tangible "orientation"' (Kearney 2015:55). The model for a contemporary theological anthropology as embodied sensing of meaning is but one effort to find this balance, to discover a grammar of the flesh, to find a grammar between the said and the unsaid, between the body and that which lies beyond the boundary of the body.

Any theology should take the body seriously. The sensing of meaning, sometimes with language and often without, is a deeply embodied experience, and words of theology about dogma or as social comment, whether it is about poverty, refugees, forgiveness, xenophobia, reconciliation, sin, incarnation or justice, should take cognisance of the profound bodily sensing involved in making meaning. In the case of the waste pickers, take note of their getting up, feeding children, climbing a fence, scavenging for recyclable and resalable refuge, their fear, apprehension, fatigue and aggression - their effort to make meaning of the concrete life they live through the bodies they have and the bodies they are. The question can now be explored how this embodied sensing of meaning relates to spatial justice, sense of place and human flourishing?

\section{On spatial justice}

The idea of spatiality asserted itself in the so-called postmodern spatial turn, which reconsidered the importance of time, space and place, especially in the aftermath of the two world wars during the twentieth century. The idea that there was a linear movement in history from barbarism to civilisation had to be abandoned and with the movement of people on a massive scale, the idea of mobility between different geographical landscapes had to be rethought (Tally 2013:13). The implication was that a person's place in the world could not be taken for granted and that displacement 'underscores the critical importance of spatial relations in our attempts to interpret, and change, the world'. Our sense of our situatedness in space, social divisions and borders, also in virtual reality, had to be reimagined because of advances in technology and increased mobility (Tally 2013:14). In geography, the cartographical map became the primary way of viewing the world as well as the distribution of power. This all changed with the onset of globalisation 'that have blurred or collapsed spatial barriers' and as these barriers collapsed, humans became more sensitive to what is contained within those spaces (Tally 2013:41). Spatiality can then be described as the mapping of 'real, imagined, and real-and-imagined spaces' (Tally 2013:146).

Andreas Philippopoulos-Mihalopoulos explores the idea of spatial justice within the lawscape, but with an emphasis on mainly human bodies. He defines spatial justice as 'the conflict between bodies that are moved by a desire to occupy the same space at the same time' (Philippopoulos-Mihalopoulos 2015:xxx). He interestingly considers withdrawal as a strategic weapon for spatial justice to emerge, where a body moves away from the desire 'to carry on with the comfort offered by supposedly free choices, power structures or even by fate' (Philippopoulos-Mihalopoulos 2015:2). He continues that through withdrawal space is orientated differently; a rupture emerges in the status quo which opens up room for renegotiation and differential movement. When he refers to bodies, it is away from any idea of anthropocentrism. He decentres the human and places the emphasis on its interconnectedness with other bodies within the Anthropocene (Philippopoulos-Mihalopoulos 2015:5), which he envisions as a space of human responsibility which emerges in the indistinction between human and other bodies (nonhuman, technological, natural, immaterial, material and elemental). The main focus of his work however remains on the human body and on what happens when bodies claim the same space. Spatial justice comes to the fore in the negotiation amongst these bodies. He continues to describe it as 'a corporeal and spatial movement that includes but is not limited to linguistic communication', perhaps harking back to my notion of embodied sensing which is more than the objectification through language.

It is however not merely about the rectification of structural power imbalances in a specific socio-cultural landscape, not about 'equally strong bodies on a flat ontology, but about unequal bodies on a tilted surface' (PhilippopoulosMihalopoulos 2015:5). He describes it as a 'flatness leaning 
sideways', meaning that the fight between bodies are not levelled, that 'some bodies are stronger than others, weigh more, pull that side of the surface down and make other, weaker bodies circulate in predetermined ways' (Philippopoulos-Mihalopoulos 2015:11). Only a momentary strategic rupture (withdrawal as a tool for spatial justice) can resolve encounters between unequal bodies. Withdrawal is then also a withdrawal from the desire of the body to allow the re-emergence of justice. He describes the rupture as 'creating a breathing space' for spatial justice, where bodies perhaps have to withdraw from presupposed positions and historical belongings, and in that moment of rupture, when bodies expose their spatiality, it allows the law (or theology in our case), to listen to the body (PhilippopoulosMihalopoulos 2015:218).

It is however important to note that judgement does not necessarily equate justice. Philippopoulos-Mihalopoulos (2015:203) cites Deleuze who writes that 'there exists a justice that is opposed to all judgment, according to which bodies are marked by each other, and the debt is inscribed directly on the body following the finite blocks that circulates in a territory'. The link between space and justice is not merely about a legal claim on a piece of land by birth. Society normally serves specific social hierarchies and power structures when holding up ownership and does not easily acknowledge 'possession, in the sense of corporeal presence and psychological projection of intent' (PhilippopoulosMihalopoulos 2015:216). He interestingly continues that space itself bears the imprint of being held up by certain spatial narratives and arrangements of bodies, not necessarily challenged by power imbalances, but by 'corporeal presences that may or may not be translatable to legal language' (and certainly theological language). Spatial justice is then this move to 'possess' space and the belief that this move will be held up by the space itself, even though it seemingly belongs to other bodies (Philippopoulos-Mihalopoulos 2015:216).

One of the stops of the group participating in the conversation on spatial justice and reconciliation was the Dutch Reformed congregation of Moreleta Park, a mega church with 14000 adult members in an affluent neighbourhood in the east of Pretoria. On a plot of land directly adjacent to the church grounds, squatters have over a few years illegally occupied a property and have erected shelters. Various legal judgements have been sought to compel these squatters to vacate the plot of land. We were not allowed access to the squatter camp, as it has not been arranged in advance and neither were we allowed to enter the property of the congregation because no appointment was made and we had to convene at the entrance outside the security gate where a representative of the squatter community addressed us.

The surface definitely seemed to be tilted, first not only by the scale of the mega church and its administrative buildings in comparison with the corrugated iron structures in the squatter camp, but also by the weight given to the black bodies of the squatters (who live in the camp from day to day) and the white bodies of the congregation (who mainly occupied the space of the congregation on Sundays). Judgements have been sought, but is justice being served? The squatters have been holding up the space through the presence of their bodies on the occupied land, and the narratives about occupying that space. Within their space are narratives of illegal immigrants gradually taking over shacks from poor black South Africans, of poor black South Africans robbing these illegal immigrants of their hard day's earnings. It seems to be about poor bodies occupying affluent territory, of black bodies possessing a white space without having the legal right of property. Alexander and Knowles (2005) write the following:

\begin{abstract}
... space always contains multiple temporalities, just as it sustains multiple and contradictory uses, meanings, associations with different kinds of people. Space both reveals social priorities whose lives and activities matters most - and provides for alternative voices, uses and versions of what matters. Space simultaneously sustains the existing, racial orders and offers the prospect of its subversion and reordering. (p. 5)
\end{abstract}

This description is supported by Goldberg (2005:220) who writes that race embodies different meanings and social structures, and that 'space and bodies enfold and materializes meanings, enacts exclusions, articulate challenges, signals dangers, project anxieties and insecurities'. This articulation of spatiality and bodies can however transmute to what is called a 'poisoned' sense of place, where other people and other places are approached with contempt, a sense of place which can become 'a platform for ethnic nationalist supremacy and xenophobia' (DeMiglio \& Williams 2008:24).

\section{On sense of place}

How does spatial justice link to sense of place? I would argue that the two relate to each other by way of the notion of embodied sensing of meaning. Similar to the idea of spatiality, humans' senseof placehas been driven by aninterconnectedness as a result of globalisation, the instantaneous availability of information through technology, receding the boundaries between places (and here it also refers to the sense of a virtual place in a virtual world), and increased mobility, with people experiencing a multiple sense of place (Williams \& Eyles 2008:203).

Sense of place is comprised by features such as the physical environment, meaningfulness, rootedness, emotional attachment, place satisfaction, place identity and belonging, with a focus on relationships (Eyles \& Williams 2008:5). Sense of place is a tangible, sensory experience of the physical environment, or an embodied sensing of a physical place. Sense of place relates to the health and well-being of the bodies within that place, and, I would argue, to the theological concept of human flourishing. DeMiglio and Williams (2008:22) describe a rooted sense of place as the feeling of 'an emotional connection to the place where one resides', which implies that there could also exist a 'placelessness' where no sense of place exists. A variety of factors can influence this sensed relationship between bodies and place like age, 
ethnicity, time, residential status as well as the physical place itself (DeMiglio \& Williams 2008:23). They continue that it takes time for people to establish a new sense of place as a result of events such as immigration and displacement. This process can happen based on what is happening in the present, while recalling the past. The geographers Kearns and Gesler (cited in DeMiglio \& Williams 2008:26) write that sense of place is determined in the interactive relationship 'between daily experiences of a (local) place and perceptions of one's place in the world ... and can be used to interpret a range of situated health effects that imply a link between mind, body and society'.

Places also have multiple meanings and the possibility of multiple associations connected to it based on activities, personal experience as well as social history, but these are closely attached to language practices (Taylor 2010:10). The use of different languages could potentially lead to the division of an 'old self' and 'new self' e.g. amongst immigrants (Craith 2012:111). The issue for many immigrants is how they could 'lose their foreign-ness while retaining a sense of self ... an elastic balance between rigidity and selfeffacement?' (Craith 2012:148). This issue is an interplay with the relation between place and identity, of belonging somewhere, of being an outsider or insider. Taylor (2010:132) interestingly writes that the quest for belonging and being at home is often tested when there is a threat to personal safety through violence.

There were narratives about the threat of violence at both the dumpsite as well as the squatter camp, because of being poor, the struggle for survival and competing for resources and also because the majority of people in these places were illegal immigrants. There were talks of the 'us' and 'them' (foreigners), the outsiders occupying our space in the squatter camp, and perhaps also in the congregation about the whole squatter camp possessing 'our' space. A qualitative research project could be undertaken in future to explore these narratives of identity, place and belonging and how it connects to spatial justice.

The group also paid an impromptu visit to another mega church along the way from Mamelodi, called the Christian Revival Church (CRC). We were reluctantly allowed access because one of the participants knew someone there. The physical space of the building was overwhelming, with the capacity to seat a few thousand people and with the newest visual and sound equipment. It is also situated at a busy junction, adjacent to an affluent property development, separated by a highway from Mamelodi township a few kilometres away. The congregation very much centred around the personality of the founding pastor who flew in by helicopter for sermons on Sundays from one of his other congregations. The reception area had the feeling of some kind of corporate headquarters, with no Christian symbols e.g. a visible display of the cross. Another pastor explained how the congregation functioned (often referring to the founding pastor), their various outreach programmes in the communities as well as how black congregants were bussed in on Sundays for the service. Once again, qualitative research should be conducted to establish the narratives that are constructed regarding place, identity, language, 'us' and 'them'. I can imagine that congregants could be searching for a sense of place of belonging; that for immigrants and locals it could be an effort to forge a new identity in a new place. What I could not imagine is how this display of success and opulence relates to the lives of mainly poor black people, especially those who are bussed in for sermons and other events, living in less than desirable circumstances. The surface seemed heavily tilted, with the power and weight lying on the side of those mainly white bodies running the megachurch. This enterprise had the sense of place where nothing could be ruptured to create a breathing space for spatial justice.

\section{On human flourishing}

Sense of place as attachment to place, as mentioned before, is connected to the idea of well-being. Manzo (2008:92) broadly defines well-being as whatever is considered in the evaluation of a person's life situation and is compared to the fulfilment of basic needs, life satisfaction and even happiness. It is heavily disrupted by displacement. This displacement of the anchoring community can result in stress, depression, problems in physical health, confusion and disorientation. Manzo (2008:94) continues that 'root shock causes a distinct threat to well-being' and cites Fullilove (2004) who writes that it is 'the traumatic stress reaction to the destruction of all or part of one's emotional ecosystem'.

This serves to illustrate how crucial sense of place is for wellbeing. I would further suggest that sense of place as the lived experience of place is an aspect of the notion of embodied sensing of meaning, and that the idea of well-being is deepened by the theological notion of human flourishing. The theological anthropology of David Kelsey served as a kind of template for my model of theological anthropology, where I explored and enhanced the clearings (areas he left open) in his work.

Kelsey (2009:4) asks his anthropological questions against the beliefs about the character of the 'proximate contexts', the physical and social world we live in, whereas the 'ultimate context' is the most fundamental and significant to what, how and who we are. He describes the proximate and ultimate contexts as 'deep parts of our personal identities', and these beliefs in the reality of God and how God actively relates to us constitute our ultimate context and cannot be changed easily (Kelsey 2009:5). We are ultimately defined as creatures in the active creativity of God although what and who we are and how we are to be are shaped by the created cosmos, the proximate contexts into which we are born (Kelsey 2009:162). This created proximate context 'is humankind's lived world in its concrete everydayness' and it is in this everydayness that its dignity lies (Kelsey 2009:191). 
This quotidian is socially constructed, made up of societies with their unique cultures and traditions, handed down from generation to generation and 'because it is always historical, and because history is diverse, the quotidian manifests remarkable diversity' (Kelsey 2009:192). He continues that all these factors contribute to the concreteness of the proximate context and to the 'every day that God creates'. It is, however, an 'every day' that is profoundly deformed by evil. Kelsey (2009:193) points out that there is no theological motivation to idealise this quotidian, and that his commitment to canonical Wisdom's creation theology is not a commitment to 'nostalgic idealizing of the world'. Humans have a vocation to be wise in their practices for the well-being of the quotidian and themselves.

Kelsey (2009:194) describes three types of practices in which humans are called to be wise: the way they interact with other humans, the way they interact with social institutions and the way in which humans interact with nonhuman creatures. Wisdom literature puts extraordinary focus on the correct use of language, exposing a normative connection between the ways language is used in complex practices. He continues that this connection underscores crucial points in theological anthropology. 'As integral parts of God's creaturely quotidian, understood as networks of practices, human creatures are above all social, intentional bodied enactors of complex, cooperative practices that necessarily include practices of language use' (Kelsey 2009:199). He continues that language, used as an integral part of wise practices, entails the use of language in a manner which is true to the persons cooperating in the practice, true to the 'nature and purpose of the relevant practice' and corresponding to the 'realities of the larger public context'. Language is then not used in a deceitful and false way. Kelsey (2009:199) boldly sums it up: 'If the quotidian is what God creates, distorting the practice is to deform creation'. The proximate context is 'inherently ambiguous' in the way we experience it. This quotidian holds the potential of the 'possibility of our well-being' as humans. At the same time it holds the potential of pain, loss and death (Kelsey 2009:202).

As humans with personal bodies we live in the knowledge that we shall die. We live on borrowed breath. The life of living in our bodies is our own 'in the sense that it simply is that human creature' (Kelsey 2009:309). He continues that we, however, never possess our 'bodied personal life' because we work with the concept of accountability to God and therefore are more like caretakers of our living bodies. Inspired by Irenaeus, Kelsey (2009:310) writes that 'the glory of God is a flourishing personal body'. He continues that human creatures are accountable to God through the manner in which they orientate their living bodies in their proximate context, defined by practices that 'make for the proximate contexts' well-being for their own sakes' and not for some kind of outcome that transcends this proximate context. God calls us to be wise and according to Kelsey our fitting response is 'faith'. He continues that it is 'in faith that personal bodies flourish as the glory of God' where he understands faith as 'wise human action in the quotidian for its well-being for its own sake'. This call to wisdom is a practical wisdom.

Kelsey (2009:319) defines human practice as 'any form of socially established cooperative human action that is complex and internally coherent, is subject to standards of excellence that partly define it'. This human action is guided by the intention to allow human beings to flourish by being wise, to flourish 'in the here-and-now quotidian world'. He continues that a Christian theological anthropology that takes human creatureliness as seriously as their eschatological consummation and reconciliation portrays humans 'as fundamentally bodied agents, not patients, bodily enactors of intentions'. This call to be wise calls for discernment and vision. Kelsey (2009:320) writes that there are no clear theories about what constitutes wise action for the well-being of other creatures. He continues that the vocation to be wise is also an invitation to 'look and listen carefully and figure it out for yourselves'. Learn wherever you can. He summarises that personal bodies flourish when wise action is discerning about 'what makes for the well-being of particular fellow creatures in their particular situations'.

Kelsey (2009:316) does not subscribe to some kind of 'abstractly ideal and absolute standard of human flourishing' against which the life of every human personal body could be measured. He does not even see such a standard in the life of Jesus. He continues to describe the flourishing of human bodily life as the 'particular finite array of powers and capacities that a given living body has and the particularities of the finite networks of relationships in which it has been set in its proximate contexts across time'. This he writes in the light of a previous remark that different creatures express the glory of God in different ways and that it expresses God's glory 'more richly' if it possesses more complex powers. Human personal living bodies are complex and rich in various types of power and are the glory of God 'in their own distinctive modes simply as living bodies creatively related to by God' (Kelsey 2009:317). Even though wisdom literature places the emphasis on a prosperous and healthy life (in line with the theme that 'being wise will make life bloom' and in its biological, cultural, emotional, social and intellectual dimensions), Kelsey (2009:318) proposes that even when personal bodies are unhealthy they still express God's glory in their unique way. This has the further implication for theological anthropology of the degree of flourishing at any given time of a human's life. The degree can vary greatly to which a specific personal body may thrive 'so that it is able to manifest the beauty of the emotional, intellectual, and social grace of which it is capable and is able to nurture both companions and descendants' (Kelsey 2009:319).

\section{Conclusion}

So how does justice smell, and specifically spatial justice? I am not quite sure, but I do sense that it is not only about the smelling of justice, but also the tasting of it, the feelings of it, the speaking of it, the hearing of it: the whole bodily experiencing of justice in a certain space. It is the embodied sensing of meaning in a space where justice is strived for. 
This space is first of all connected to a specific, local place where belonging and attachment, a person's sense of place heavily impacts on their well-being in a concrete and specific life-world. I would agree that the optimum physical, mental and social well-being of human and nonhuman bodies in a concrete, local place is intended in the idea of spatial justice. Within theological anthropology the notion of human flourishing embraces well-being and expands it, where human flourishing is to allow yourself and other bodies, human and non-human to thrive (in different degrees within biological, cultural, emotional, social and intellectual dimensions) as bodily agents within the proximate quotidian (a local, concrete place) and within the relationships one have to other creatures and institutions, through wise action and in accountability to God in the way we live in the bodies that we have and the bodies that we are.

It seems that spatial justice requires some kind of rupture, a tearing to appear in the atmosphere of a place or between places where bodies endeavour to make meaning, and where the embodied sensing of meaning also includes the striving for justice. The space for justice is held up by the embodied narratives and intent of those bodies that want to occupy the space, where bodies from different places have the desire to possess the same space.

The upholding of spatial justice as an embodied action does not only require good judgement, legal or otherwise, but it also requires a certain practical wisdom and wise action, to look and listen carefully, to learn and then to discern what will allow human and non-human bodies to flourish in their particular, local place where they strive to make meaning.

\section{Acknowledgements Competing interests}

The author declares that he has no financial or personal relationships which may have inappropriately influenced him in writing this article.

\section{References}

Alexander, C. \& Knowles, C., 2005, 'Introduction', in C. Alexander \& C. Knowles, (eds.), Making race matter: bodies, space and identity, pp. 1-16, Palgrave Macmillan, Hampshire.

Craith, M., 2012, Narratives of place, belonging and language, Palgrave Macmillan, Hampshire.

DeMiglio, L. \& Williams, A., 2008, 'A sense of place, a sense of well-being', in J. Eyles \& A. Williams (eds.), Sense of place, health and quality of life, pp. 15-30, Ashgate, Surrey.

Eyles, J. \& Williams, A., 2008, 'Introduction', in J. Eyles \& A. Williams (eds.), Sense of place, health and quality of life, pp. 1-14, Ashgate, Surrey.

Fullilove, M., 2004, Root shock: how tearing up city neighbourhoods hurts America, and what we can do about it, Ballentine Books, New York.

Goldberg, D.T., 2005, 'Afterwards', in C. Alexander \& C. Knowles, (eds.), Making race matter: bodies, space and identity, pp. 218-223, Palgrave Macmillan, Hampshire.

Kearney, R., 2015, 'The wager of carnal hermeneutics', in R. Kearney \& B. Treanor (eds.), Carnal hermeneutics, Fordham University Press, New York.

Kearney, R. \& Treanor, B., 2015, 'Introduction: Carnal hermeneutics from head to foot', in R. Kearney \& B. Treanor (eds.), Carnal hermeneutics, Fordham University Press, New York.

Kelsey, D.H., 2009, Eccentric existence: A theological anthropology, vols. 1 \& 2, Westminster John Knox Press, Louisville, KY.

Lakoff, G. \& Johnson, M., 1999, Philosophy in the flesh. The embodied mind and its challenge to Western thought, Basic Books, New York.

Manzo, L., 2008, 'The experience of displacement on sense of place and well-being', in J. Eyles \& A. Williams, Sense of place, health and quality of life, pp. 87-104, Ashgate, Surrey.

Mbomvu, N., 2015, 'Groundup: Waste pickers protest over access to dump site', viewed 26 April 2016, from http://www.dailymaverick.co.za/article/2015-11-12groundup-waste-pickers-protest-over-access-to-dump-site/\#.VyMotYR97IV

Meiring, J., 2015, 'Theology in the flesh - A model for theological anthropology as embodied sensing', HTS Teologiese Studies/Theological Studies 71(3), 5 of 8, Art. \#2858, 1-8. http://dx.doi.org/10.4102/hts.v71i3.2858

Nelson, J.B., 1978, Embodiment: An approach to sexuality and Christian theology, Augsburg Publishing House, Minneapolis, MN.

Nelson, J.B., 1992, Body theology, Westminster John Knox Press, Louisville, KY.

Nelson, J.B., 2004, Thirst: God and the alcoholic experience, Westminster John Knox Press, Louisville, KY.

Philippopoulos-Mihalopoulos, A., 2015, Spatial justice: Body, lawscape, atmosphere, Routledge, New York.

Pillay, K., 2015, 'War on waste pickers', News24, viewed 27 April 2016, from http:// www.news24.com/SouthAfrica/News/War-on-waste-pickers-20151105

Sheets-Johnstone, M., 2009, The corporeal turn. An interdisciplinary reader, Imprint Academic, Exeter.

Tally, R., 2013, Spatiality, Routledge, New York.

Taylor, S., 2010, Narratives of identity and place, Routledge, East Sussex.

Todres, L., 2011, Embodied enquiry: Phenomenological touchstones for research, psychotherapy and spirituality, Palgrave Macmillan, Hampshire.

Williams, A. \& Eyles, J., 2008, 'Conclusion', in J. Eyles \& A. Williams, Sense of place, health and quality of life, pp. 197-211, Ashgate, Surrey. 